\title{
Perforation of the small intestine caused by enteropathy- associated T cell lymphoma
}

\author{
Selva Kabul' ${ }^{10}$, Nesrin Uğraș ${ }^{1}$, Ömer Yerci', Ersin Öztürk²
}

\begin{tabular}{ll}
\hline ABSTRACT & Enteropathy-associated T cell lymphoma is a rare lymphoma specific to the gastrointestinal system, arising from \\
intraepithelial T lymphocytes, that is often associated with celiac disease. We report a 53-year-old female patient \\
with no previous disease who presented with severe abdominal pain. Physical examination revealed diffuse ab- \\
dominal tenderness and abdominal guarding and the patient underwent emergency surgery with a diagnosis of \\
acute abdomen. During the operation, a 20-cm mass was found located on Treitz ligament, invading the duodenum \\
and pancreatic head and perforating the jejunum. Histologically, medium-sized monomorphic atypical lymphocyte \\
infiltration with dark nucleus and narrow cytoplasm was seen in the layers of mucosa, submucosa, muscular wall, \\
and serosa of the duodenum. The final pathological diagnosis was "enteropathy-associated T cell lymphoma type \\
2" based on immunohistochemical and serological findings. Based on the World Health Organization 2008 criteria, \\
enteropathy-associated T cell lymphoma has two subtypes. Type 1 enteropathy-associated T cell lymphoma is as- \\
sociated with celiac disease and has HLA DQ2 and HLA DQ8 genotype. Enteropathy-associated T cell lymphoma 2 \\
enteropathy-associated T cell lymphoma seldom occurs and is not associated with celiac disease. \\
Keywords: Lymphoma, enteropathy, small intestine
\end{tabular}

ORCID ID of the author: S.K. 0000-0001-7864-6694

Cite this paper as: Kabul S, Uğraş N, Yerci Ö, Öztürk E. Perforation of the small intestine caused by enteropathy-associated T cell lymphoma. Turk J Surg 2018 34 (3): 253-255.

'Department of Surgical Pathology, Uludağ University School of Medicine, Bursa, Turkey ${ }^{2}$ Department of General Surgery, Uludağ University School of Medicine, Bursa, Turkey

Corresponding Author Selva Kabul

e-mail:selvakaraman@hotmail.com

Received: 09.07.2015

Accepted: 14.09 .2015

Available Online Date: 03.01.2018

(c) Copyright 2018

by Turkish Surgical Association

Available online at

www.turkjsurg.com

\section{INTRODUCTION}

Enteropathy-associated T cell lymphoma (EATL) is an extranodal lymphoma that has a poor prognosis arising from intestinal intraepithelial T lymphocytes. Although it has a very rare incidence in most parts of the world, it is more common in societies where celiac disease is widespread $(1,2)$.

According to the World Health Organization (WHO) criteria, it has two subtypes: type 1 and type 2. Type 1 EATL is associated with celiac disease and it comprises $80 \%-90 \%$ of cases observed in Europe. Type 2 EATL, occurring sporadically, is less frequently associated with celiac disease and is more common in Asian countries (3).

A case of EATL presenting with intestinal perforation is reported due to its rare incidence and discussed with the literature.

\section{CASE PRESENTATION}

A 53-year-old female patient with no previous disease presented with severe abdominal pain. Physical examination revealed diffuse abdominal tenderness and abdominal guarding. Laboratory data revealed leukocytopenia $\left(1780 / \mathrm{mm}^{3}\right)$ with normal values for hemoglobin $(13.3 \mathrm{~g} / \mathrm{dL})$ and platelets $\left(237 \times 10^{6} /\right.$ $\mathrm{mm}^{3}$ ). Her other routine laboratory findings were normal. With these findings, the patient underwent emergency surgery with a diagnosis of acute abdomen. During operation, a 20-cm mass was found, located on Treitz ligament, invading the duodenum and pancreatic head and perforating the jejunum. An intraoperative biopsy specimen was sent for pathological diagnosis, which suggested a malignant lymphoid cell infiltration, and accordingly a partial intestinal resection and Roux-en $\mathrm{Y}$ anastomosis was performed.

Grossly, the resected specimen contained $5 \mathrm{~cm}$ of duodenum and $35 \mathrm{~cm}$ of jejunum with adjacent tissues. A $7 \times 5 \mathrm{~cm}$ submucosal mass, invading the wall of duodenum and jejunum and resulting in mucosal ulcer and perforation, was found. It was a gray-white colored tumoral mass with occasional bleeding areas.

Microscopically medium-sized monomorphic atypical lymphocyte infiltration with dark nucleus and narrow cytoplasm was seen in the layers of mucosa, submucosa, muscular wall, and serosa of the duodenum (Figure 1). There was no inflammatory background but tumor cell necrosis was found in some areas. In the non-neoplastic intestinal mucosa, villous atrophy, cryptal hyperplasia, intraepithelial lymphocytosis, and lymphoplasmacytic infiltration in lamina propria were observed (Figure 2). In the im- 


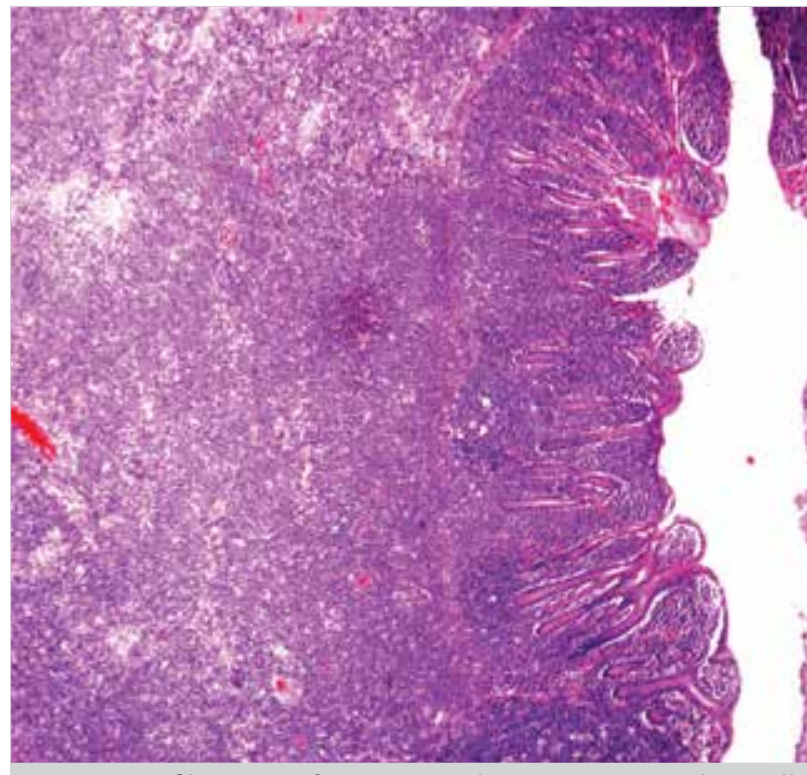

Figure 1. Infiltration of mucosa, submucosa, muscular wall, and serosa of the duodenum by atypical lymphocytes (H\&E; 200x)

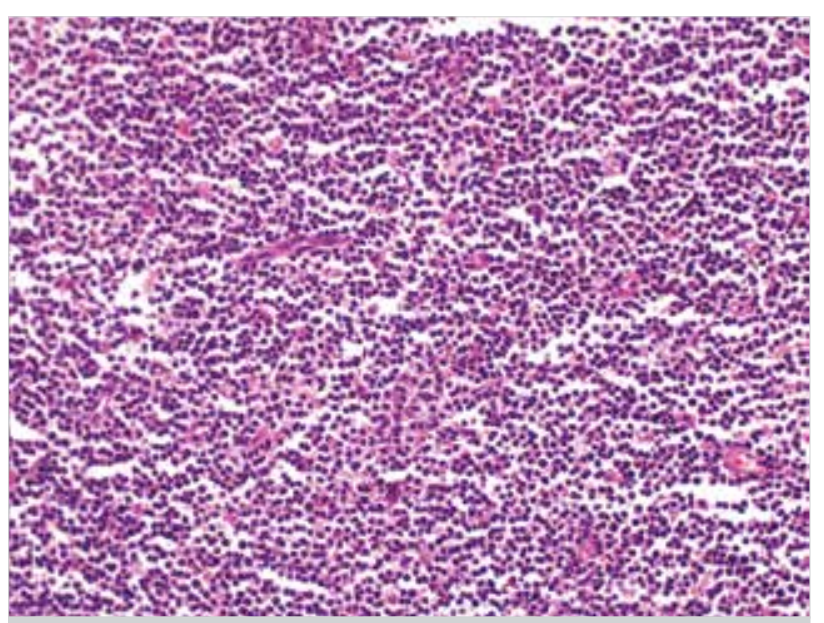

Figure 2. Medium-sized monomorphic atypical lymphocytes (H\&E; 400X)

munohistochemical analysis, the tumor cells were positive for LCA, CD3, CD7, CD8, and CD56, and negative for CD20, CD5, CD4, CD79a, CD10, CD99, and CK. Ki67 proliferation activity was $70 \%$. The intraepithelial lymphocytes in the adjacent mucosa had identical immunophenotype with tumor cells. The serological examination was negative for HLA DQ2 and HLA DQ8 expression. The final pathological diagnosis was "EATL type 2 " according to above mentioned findings. The patient have been informed and also her consent have been taken for this case report.

\section{DISCUSSION}

The most common site for primary extranodal lymphomas is the gastrointestinal tract and majority have B cell phenotype. Primary T/NK cell lymphomas seldom occur but are more aggressive tumors (4).

Enteropathy-associated T cell lymphoma is a rare lymphoma, which is specific to gastrointestinal system, arising from with celiac disease. EATL is often observed in middle-aged men and is localized in the small intestines. Almost half of cases are presented with intestinal obstruction or perforation. Although rarely observed, EATL is one of the main causes of mortality in untreated or refractory celiac disease $(5,6)$.

Based on the WHO 2008 criteria, EATL has 2 subtypes. Type 1 EATL is associated with celiac disease, and has HLA DQ2 and HLA DQ8 genotype (7). On microscopic examination, the tumor cells are medium- or large-sized cells with round or angulated vesicular pleomorphic nuclei and abundant cytoplasm. They are positive for CD3 and negative for CD8 and CD56 immunohistochemically. Typically, the tumor has extensive necrosis areas and an inflammatory background rich of eosinophils, neutrophils, and histiocytes. Large cells with CD30 expression are occasionally seen in the type 1 EATL. In type 2 EATL, which seldom occurs and is not associated with celiac disease, tumor cells have small- to mediumsized round, darkly staining monomorphic nuclei and narrow cytoplasm. There is no inflammatory background and marked necrosis. As seen in our case, the neoplastic cells are stained positively for CD3, CD8, and CD56 immunohistochemically. In both types, the adjacent mucosa shows villous atrophy, crypt hyperplasia, and increased intraepithelial lymphocytes, having same immunophenotype with the tumor cells $(3,8)$.

Differential diagnosis of EATL includes B cell lymphomas, especially diffuse large $B$ cell lymphoma, which is the most common type of lymphoma in the small intestine. The positivity of B lymphocyte markers in all types of B cell lymphomas helps distinguish these tumors from EATL. Extranodal NK/T cell lymphomas, in general presenting with facial mass, are rarely diagnosed with intestinal metastasis and confused with EATL due to its morphological heterogeneity. Distinctive features of NK/T cell lymphomas are the positivity of NK (CD2) and EBV markers and absence of histopathological findings of enteropathy in the surrounding mucosa (9).

The poorly differentiated carcinomas and malignant melanomas, subject to differential diagnosis, can easily be excluded immunohistochemically. In absence of mass formation, EATL can be confused with an inflammatory ulcer, but the presence of atypical cells in EATL excludes this diagnosis $(10,11)$. $B$ cell lymphomas, poorly differentiated carcinomas, and benign lesions were excluded in our case with the presence of monomorphic atypical tumor cells stained positively for T lymphocyte markers. Our case was diagnosed as intestinal EATL type 2, because of the monomorphic and small appearance of tumor cells, absence of inflammatory background, positive staining for CD3, CD8, and CD56, and lack of celiac disease findings, although focal necrosis was seen in some areas. Cyclophosphamide, adriamycin, vincristine, and prednisolone (CHOP) protocol was planned for treatment. The patient was lost within two months postoperatively due to fever, pleural effusion, and respiratory failure.

\section{CONCLUSION}

Gastrointestinal lymphomas can be presented with the symptoms of acute abdomen, but not with systemic findings as in our case. 
Informed Consent: Written informed consent was obtained from patient who participated in this study.

Peer-review: Externally peer-reviewed.

Author Contributions: Concept - S.K.; Design - S.K., N.U.; Supervision - N.U., Ö.Y.; Resource - S.K., Ö.Y.; Materials - E.Ö., Ö.Y.; Data Collection and/or Processing - E.Ö., S.K.; Analysis and/or Interpretation - S.K., Ö.Y.; Literature Search - S.K., N.U., Ö.Y.; Writing Manuscript - S.K., N.U.; Critical Reviews - Ö.Y., E.Ö.,

Conflict of Interest: The author have no conflicts of interest to declare.

Financial Disclosure: The authors declared that this study has received no financial support.

\section{REFERENCES}

1. Isaacson PG, Du MQ. Gastrointestinal lymphoma: where morphology meets biology. J Pathology 2005; 205: 255-274. [CrossRef]

2. Delabie J, Holte H, Vose JM, Ullrich F, Jaffe ES, Savage KJ, et al. Enteropathy associated T-cell lymphoma: Clinical and histological findings from the International Periferal T-Cell Lymphoma Project. Blood 2011; 118: 148-155. [CrossRef]

3. Isaacson $P$, Wright $D$, Ralfkiaer E, Jaffe ES. Enteropathy-type T-cell lymphoma. In: Jaffe ES, Harris NL, Stein H, Vardiman JW. WHO classification of Tumours of hematopoietic and lymphoid tissues. Lyon: IARC 2008: 208-209.

4. Sun J, Lu Z, Yang D, Chen J. Primary intestinal T-cell and NK-cell lymphomas: A clinicopathological and molecular study from Chi- na focused on type II enteropathy- associated T-cell lymphoma and primary intestinal NK-cell lymphoma. Modern Pathology 2011; 24: 983-992. [CrossRef]

5. Malamut G, Chandesris O, Verkarre V, Meresse B, Callens C, Macintyre $\mathrm{E}$, et al. Enteropathy associated $\mathrm{T}$ cell lymphoma in celiac disease: A large retrospective study. Digestive and Liver Disease 2013; 45: 377-384. [CrossRef]

6. Isaacson $\mathrm{P}$, Wright $\mathrm{DH}$. Intestinal lymphoma associated with malabsorption. Lancet 1978; 1: 67-70. [CrossRef]

7. Deleeuw RJ, Zettl A, Klinker E, Haralambieva E, Trottier M, Chari R, et al. Whole-genome analysis and HLA genotyping of enteropathy-type T-cell lymphoma reveals 2 distinct lymphoma subtypes. Gastroenterology 2007; 132: 1902-1911. [CrossRef]

8. Chott A, Haedicke W, Mosberger I, Födinger M, Winkler K, Mannhalter C, et al. Most CD56+ intestinal lymphomas are CD8+ CD5- T-cell lymphomas of monomorphic small to medium size histology. American Journal of Pathology 1998; 153: 1483-1490. [CrossRef]

9. Doğanavşargil B, Karaarslan S, Sarsık B, Tekin F, Seziş M, et al. Evaluation of the relationship of Epstein-Barr virus by Eber in-situ hybridization in cases of Enteropathy-type T-cell lymphoma. Türk Patoloji Dergisi 2008; 24: 6-13.

10. Chandesris O, Malamut G, Verkarre V, Meresse B, Macintyre E, Delarue $\mathrm{R}$, et al. Enteropathy associated T-cell lymphoma: A review on clinical presentation, diagnosis, therapeutic strategies and perspectives. Gastroenterol Clin Biol 2010; 34: 590-605. [CrossRef]

11. Wang L, Liu Y, Lin Y. A case of enteropathy associated T-cell lymphoma (Type I) arising in stomach without refractory celiac disease. Diagn Pathol 2012; 7: 172-177. [CrossRef] 